The Labore Journal of Economics

10 : 2 (Winter 2005) pp. 111-140

\title{
Corruption and Trade Liberalization: Has the World Bank Anti-Corruption Initiative Worked? ${ }^{1}$
}

\section{Azam Chaudhry*}

\section{Introduction}

In September 1997, the World Bank formally began its anticorruption initiatives by adopting a series of official guidelines and policy statements to aid in anti-corruption strategies. One of the main areas of focus is international trade. According to World Bank (1997), the areas in which corruption is most often found is in, "customs and tax departments, social security agencies, land titling and environment agencies administering regulations and issuing licenses, public works departments and other agencies involved in significant public procurement, police and judiciary, and privatization agencies." In particular, trade policies can be susceptible to corruption, even though many countries have successfully managed trade policies to promote industrialization. This susceptibility of trade policies to corruption is because they involve allocations made by the authorities on discretionary rather than efficiency bases. Examples of this are the discretionary actions of customs officials, the administrative actions of the authorities in the allocation of import licenses and foreign exchange, and bribery involved in maintaining high rates of tariffs.

Despite this obvious link, there has been some debate about the nature of the corruption-international trade relationship. One strand of thought has analyzed the effects of corruption on international trade. Lambsdorff (1998) and Anderson and Marcouiller (1999) describe how corruption reduces international trade, because importers and exporters are discouraged by a system of bribery, uncompetitive bidding, selective taxation and artificially created monopolies. The implicit assumption is that the chain of causality runs from corruption to trade, i.e., to increase international trade, one must reduce the level of corruption. The second

\footnotetext{
${ }^{1}$ This paper is based upon research that the author conducted for the World Bank. The paper represents the views of the author only and does not necessarily reflect the views of the World Bank or its Executive Directors.

* Associate Professor, Dept of Economics, The Lahore School of Economics, Lahore
} 
strain of thought reverses the chain of causality. Thus Ades and di Tella $(1995,1996,1997)$ claims that it is the level of international trade that is one factor (of the many factors) that affects the level of corruption. The argument is that trade liberalization, which results both in the enlarging of the scope and increasing the efficiency of the market, should make markets more competitive. This reduces the level of available rents, which in turn leads to a reduction in the amount of corruption in the economy.

This paper adopts the second viewpoint, i.e. international trade makes an economy more competitive which in turn leads to less corruption. Ades and di Tella $(1995,1997)$ empirically proved the hypothesis that openness, as measured by the amount of imports (as a proportion of the GDP) and the level of tariffs, affected the level of corruption. An internal Bank research study analyzes the same relationship by using the average level of trade tariffs and the percentage of import goods subject to quota restrictions (for a larger sample than Ades and di Tella), and gets similar results. This paper furthers their research by empirically analyzing how the levels of specific trade taxation (import tariffs, export duties and quota reductions), and the level of trade (as a proportion of GDP) affect the level of corruption in an economy. This analysis is performed in the context of World Bank initiatives on trade liberalization over the last two decades.

Besides the basic question of the impact of trade liberalization on corruption, this paper also attempts to answer another question: Have the World Bank's initiatives in the sphere of trade reform been successful in reducing the level of corruption? Nash et al (1991) and Michaely et al (1991), found that while substantial progress in the area of reductions is quota restrictions $(\mathrm{QR})$ and in the removal of licensing, prohibitions and export taxes, far less progress was made in the area of substantial tariff reform (Dean, page 15). This may imply that while the Bank's general strategy of trade liberalization was successful, countries had trouble finding alternative sources of revenue and thus were reluctant to remove import tariffs (which is a major source of corruption). Thus in the short to medium term, corruption may not be significantly affected by 'successful' trade liberalization policies.

The structure of this paper is as follows: Part II: An analysis of how trade reform can affect the level of corruption in an economy. Part III: An analysis of World Bank's involvement in the area of trade liberalization and how this should impact corruption. Part IV: A simple model to explain the relationship between corruption and trade liberalization. Part V: An empirical analysis of the relationship between corruption and trade liberalization. Part VI: Conclusions. 


\section{Relationship Between Trade Liberalization and Corruption}

The purpose of this section is to present the theoretical relationship between trade liberalization and corruption. As much of the literature on corruption points out, corruption results from the authority (or 'monopoly power') held by certain individuals in an economy, which is used to extract rents in the form of illegal payments and other 'favors'. This authority may permit an official to allocate a commodity at a price below the market equilibrium level, which may result in rent-seeking behavior. Similarly, in the sphere of international trade, this authority may permit an official to regulate the price and quantity of a traded good, decide who is permitted to trade a particular good or decide the exchange rate at which goods are traded. In particular, governmental officials may be permitted to put quantitative restrictions on traded goods, set tariffs on imported goods, tax exported goods and maintain an overvalued exchange rate. Each of these actions may result in increased levels of corruption in an economy and an analysis of the mechanism through which rents are obtained can explain how trade liberalization affects corruption.

\section{Removal of Quotas and other Quantitative Restrictions}

Quantitative restrictions (such as quotas) are the result of officials setting limits on the quantity of (certain) traded goods. Tanzi (1993) discusses how quasi-fiscal regulations (i.e. regulations that substitute for taxing and spending), such as quotas, may occur in economies that have particular trade objectives but are having problems in raising the level of taxation. These restrictions may give rise to corruption, since they may result in lobbying by certain sectors of the economy for protection from international competition. Similarly, corrupt activities can flourish in the process in which officials determine how much of a particular good should be allowed as imports and in the process during which import licenses are issued.

But trade liberalization in the form of a complete elimination of quantitative restrictions may not be economically and politically feasible. Alternatively, Dean, Desai and Riedel (1994) describe how restrictions such as quotas should be turned into tariffs to restrict the opportunities for rentseeking. One cannot say for certain that transformation of quota restrictions into tariffs will lead to lower levels of corruption, but the level of corruption may be counterbalanced by increased government revenues, less inequality among industries and less uncertainty regarding access to imported inputs. It should be noted that complete elimination of non-tariff barriers would have a significant impact on the level of corruption in an 
economy. But in practice, non-tariff barriers are replaced by tariff barriers, and thus the impact on corruption of the removal of non-tariff barriers is modest.

\section{Abolition of Tariffs}

The tariff system is the most substantial way in which protectionist trade policies affect the level of corruption. As Pritchett and Sethi point out, tariffs on imports generate corruption at two levels. The first level at which corruption is generated is at the revenue collection level. The larger the potential revenues from import tariffs, the greater will be the incentive to offer bribes to revenue collecting officials. These bribes may be to obtain exemptions from import tariffs or to underestimate the level of tariffs due. The second level at which corruption occurs is at the industry level. Firms now have a greater incentive to engage in underinvoicing, misdeclaration and smuggling as the tariff level gets higher.

A major issue that arises in trade liberalization through the abolition of a tariff system is that certain economies may be heavily dependent on the revenues from tariffs. If the immediate abolition of import tariffs is not feasible, the second best alternative is to have a tariff structure that has the least amount of dispersion (which is the variance in tariff rates across goods). This is because a pre-commitment to a tariff rule with minimal variance means that the tariff rate established is prevalent in most sectors, introducing a free-rider problem for groups that are lobbying for protection (through possibly corrupt means). To limit the dispersion of import tariffs, there are two possible alternatives: (i) A uniform tariff rule (implying that tariffs are constant across all commodities); (ii) a series of concertina reductions (which is the process of reducing the highest tariff rates to a specified level while leaving lower rates intact, and then repeating this process until the tariffs have reached a uniform, predetermined level). ${ }^{2}$ This reduction in dispersion should have the effect of reducing the incentives for corrupt activities, while the eventual abolition (or low and uniform level) of tariffs should lead to further reductions in corruption.

\section{Removal of Export Taxes and Subsidies}

Export taxes and subsidies also provide opportunities for corruption. The discussion of export taxes closely mirrors the discussion on tariffs. The argument presented above concerning the importance of tariff reduction and

\footnotetext{
${ }^{2}$ Michely, Papageourgiou and Choksi (1991)discuss how the second method results in the least dispersion of tariffs at every stage of tariff reduction.
} 
reductions in corruption is also relevant in this section, though empirically it can be shown that export taxes contribute far less (than import tariffs) to government revenues. This, in turn, implies both lower levels of corruption and also less reluctance on the part of the authorities to decrease (or eliminate) the levels of export taxes. Export subsidies (on the other hand) are susceptible to corruption because bribes (and/or improper influence) can be used by a certain sector to become the recipient of subsidies. Though in trade theory it is found that export subsidies can be used in conjunction with import tariffs to improve the competitiveness of an economy, gradual reductions in both are needed to combat corruption.

Practically, revenues from export taxes are much smaller than revenues from import taxes. Also, the coverage of import taxes is wider than that of export taxes, in terms of the number of goods covered and the level of effective protection. This implies that initiatives aimed at reducing the levels of export taxes will have modest effects on the level of trade liberalization and the level of corruption.

\section{Exchange Rate Adjustment}

Exchange rate adjustment usually occurs in the form of a real depreciation in the currency to accompany policies of trade liberalization. Overvalued exchange rates give rise to illegal markets in foreign exchange and corruption in the system of purchasing foreign exchange from the monetary authorities. But not only is a devaluation necessary, market forces must be allowed to intervene. As Nash and Takacs (1998) explained: "The main lesson is that ensuring the right exchange rate is important in a trade reform program, but the right exchange rate alone is not enough. The entire foreign exchange rate mechanism must be flexible, transparent, and efficient... As long as the allocation of foreign exchange for some or all imports is discretionary, import liberalization cannot advance very far because protection remains opaque and dispersed," (page 6). Exchange rate liberalization has a substantial effect on trade liberalization and corruption, not only because of the fact that market determined exchange rates imply smaller opportunities for corruption in the process of obtaining foreign exchange, but also because the rationalization of exchange rates complements other trade liberalization policies. It is important to note that in some countries financial liberalization of this sort may not be an option (due to reasons such as macroeconomic instability). In this case, the level of corruption can still be reduced by introducing greater transparency in the method in which foreign exchange is dispensed (e.g. through an auction system). 


\section{The World Bank's Involvement in the Sphere of Trade Liberalization}

Since the 1970's, the World Bank has pursued a trade liberalization policy, though it was in the 1980's that a large number of developing countries began to liberalize trade unilaterally. To understand the effects of the Bank's trade liberalization policies on corruption, it would be useful to analyze the types of reforms that were initiated and how these reforms have affected the level of corruption in a country. Initially, the World Bank's ALCID database will be used to determine the types of trade-related initiatives the World Bank has adopted. After this, the outcomes of the trade-related initiatives will be rated to determine their success. For these ratings, two different sources will be used: The first is a series of studies of the World Bank's trade-related initiatives. The second is the World Bank's Operations and Evaluation Department (OED) ratings for project outcomes.

\section{The World Bank's Trade-Related Initiatives}

The World Bank began to focus on trade reform in the 1980's, using both adjustment loans with trade-related conditionalities and trade-specific loans. Figure 1 (based on information taken for the ALCID database), shows that the Bank's trade-related projects began to grow substantially in the mid-1980's. It also illustrates how the Bank began its efforts by incorporating trade-related conditionalities into adjustment loans in the 1980 's, and then began to increase the number of trade-specific projects in the early 1990's. Eventually, the Bank used both methods with (approx.) equal frequency.

Figure-2 illustrates the three major tools the World Bank uses in its trade-related projects. Quota reduction, tariff reduction and export promotion have been the three major reform areas that the Bank has concentrated on. Two things can be observed from the figure. First, the three elements of trade reform have been used with the same frequency from the years 1980-19903. Second, the importance of trade-related initiatives in Bank projects was at its peak in the early to mid-1980's, when they were included in approximately $30-50 \%$ of all Bank projects. After this point, the percentage of projects that included trade-related initiatives has remained steady at about $20 \%$, with a decline to about $10 \%$ in the 1990 's.

This discussion illustrates the stress the Bank has placed on traderelated initiatives in the 1980's and 1990's. Also, the Bank has focused on

\footnotetext{
${ }^{3}$ These are the years for which the ALCID database has information on implementation of conditionalities.
} 
three areas of reform: quota reform, tariff reform, and export promotion. It may be useful to see the success with which the World Bank has tackled these areas.

Figure-1: Trends in the World Bank's Trade-Related Lending
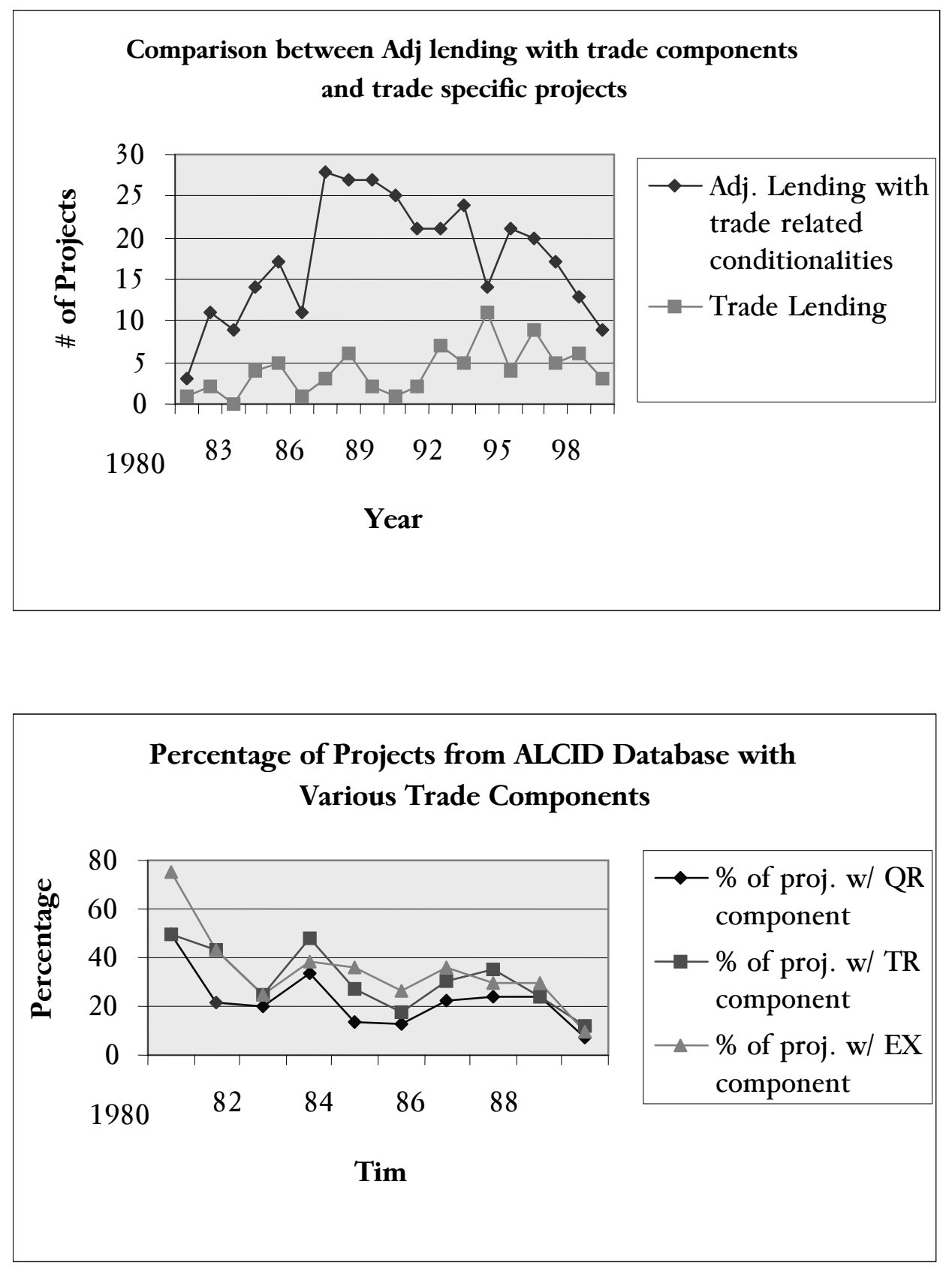


\section{Rating the World Bank's Trade-Related Initiatives}

In order to rate the effects of the World Bank's trade-related initiatives, one can first analyze three comprehensive studies on liberalization policy published by the World Bank: (1) V. Thomas, J. Nash and Associates, Best Practices in Trade Policy Reform, 1991 (TN); (2) D. Papageourgiou, A. Choksi and M. Michaely, Liberalizing Foreign Trade in Developing Countries: Lessons of Experience, 1990 (PCM); and (3) J. Dean, S. Desai and J. Riede1, Trade Policy Reform in Developing Countries since 1985, 1994 (DDR). The first analyzes liberalization episodes in 88 developing countries during the early 1980's (focusing on 24 countries that received trade adjustment loans). The second focuses on early reforms in 19 countries dating back from the 1950's and continuing to 1984. The final study examines the nature and extent of trade liberalization in 32 countries in South Asia, Africa, Latin America and East Asia from the mid 1980's to 1993. These studies will be used to create a series of outcome ratings for the four areas the Bank has concentrated its trade reform efforts on: (i) the removal of quotas, (ii) the removal of tariffs, (iii) export promotion and (iv) the rationalization of the exchange rate. Each area of policy reform was given a rating of Negligible, Modest, Substantial or High.

Also in each of the four areas mentioned above, a separate series of ratings was created using OED project outcome ratings (either Satisfactory or Unsatisfactory), for a sample of 115 trade-related projects. First, these projects were categorized as projects relating to quota reduction, tariff reduction, export promotion or exchange rate stabilization ${ }^{4}$. Then the average outcome rating was taken for all the projects in each of the categories (with a satisfactory rating being assigned the number 1 , and an unsatisfactory rating being assigned the number 0 ). Finally, in order to convert this into a ratings scale comparable to the one above, the average outcome rating of the projects in each area was converted as follows: $0-0.25=$ Negligible; $0.26-0.5=$ Modest; $0.51-0.75=$ Substantial; and $0.76-1.00=$ High. These ratings were then averaged with the ratings determined in the paragraph above to obtain an overall outcome rating for World Bank initiatives in each of the four trade-related areas determined from the studies above.

\section{World Bank Initiatives to Remove Non-Tariff Barriers}

The analysis of quota reduction policies yields similar results across the three studies. During the time periods mentioned above, all three

\footnotetext{
${ }^{4}$ Though it should be noted that one project can have numerous conditionalities, and thus may be included in more than one category of trade reform.
} 
studies found that countries had made substantial progress in eliminating non-tariff barriers. PCM and TN found a significant number of instances during which countries reduced quotas, with PCM in particular finding that quota reductions were accompanied by devaluations (though no lowering of tariffs). DDR found that a large number of countries in Latin America, East Asia and Africa virtually eliminated explicit quota restrictions (though South Asia had made little progress in reducing quota restrictions), and had replaced these quota restrictions with tariffs. As DDR explained, "It is unclear whether the level of protection on these goods (subject to non-tariff barriers) rose or fell when QRs were replaced by tariffs. However, certainly incentives for rent-seeking were reduced and transparency increased. Since QRs were the binding constraint on trade in many countries, these reductions do represent a significant move toward liberalization," (page 96). Thus the outcome rating in this area, based on the studies mentioned above, is Substantial.

The average OED outcome rating for projects with conditionalities in the area of non-tariff barriers is 0.660 , or substantial.

\section{World Bank Initiatives to Remove Tariffs}

The evidence on the extent of tariff reform is less obvious, but generally points towards modest progress in the area of tariff reform. PCM find significant decreases in tariffs in fewer than half of the episodes, with a wide variety of methods used (ranging from the concertina method to no method at all). On the other hand, TN found that a large number of cases in which significant progress had been made on tariff reform, with reforms ranging from reductions in the number of rates, the maximum rate and the number of extensions to establishing lower minimum tariffs. However, TN went on to admit that modest progress had been made on reducing the average tariff level and that the dispersion in effective protection remained significantly wide. DDR found that only Latin American countries had made significant progress in lowering the number and dispersion of their tariff rates, and that countries that were highly dependent on tariff revenues were more likely to have higher levels of tariffs after the period of reform. The overall picture that one gets is that tariff reform is progressing steadily, but countries are still reluctant to completely eliminate tariffs due to the central role they occupy in their public finances. The evidence above implies a Modest outcome rating for the Bank's tariff related initiatives.

The average OED outcome rating for projects with conditionalities in the area of tariff barriers is 0.483 , or Modest. 


\section{World Bank Initiatives to Promote Exports}

All three studies found that substantial progress had been made by the countries in promoting exports. TN and PCM found that countries had been quite successful in removing licenses, prohibitions and export taxes, with PCM further finding that direct export incentives were prevalent. DDR also found significant removals of direct disincentives for exporters, which in some cases were replaced with new (though badly designed and inefficient) incentives for exporters. Though all the countries analyzed in the three studies (with the exception of a few South Asian countries) had made substantial progress in removing direct disincentives on exports, all three studies found that far less progress had been made in the area of active export promotion. Thus the outcome rating for this area is Modest.

The average OED outcome rating for projects with conditionalities in the area of export promotion is 0.641 , or substantial. Note that the average OED rating differs from the rating obtained from the three studies discussed above.

\section{World Bank Initiatives to Rationalize Exchange Rates}

All the aforementioned studies found that real devaluation of the exchange rate was a necessary step for successful trade liberalization. PCM discusses how very few of the analyzed reform episodes had real appreciations accompanying them, while TN noted that countries receiving trade adjustment loans had greater real depreciations of their exchange rates. DDR found that the majority of the 32 countries under study had aimed towards real exchange rate depreciation, and that those countries with the largest black market premia achieved the largest and most sustained depreciations. Thus World Bank initiatives in the area of exchange rationalization have had substantial success, and the outcome rating for these initiatives is Substantial.

The average OED outcome rating for projects with conditionalities in the area of non-tariff barriers is 0.736 , or substantial.

\section{Conclusions on World Bank Initiatives}

The conclusions that one can draw is that the World Bank has successfully focused on the major trade reform initiatives in its lending. The reform process follows a certain sequence, with the removal of nontariff barriers and the rationalization of the exchange rate being the initial steps, followed by the promotion of exports (and the removal of 
export taxes), and reaching a point where the economy is ready to significantly reduce its import taxes. World Bank lending has been successful in the areas of non-tariff barrier removal and exchange rate rationalization, but has been less so in the areas of export promotion and import tariff removal. This means that the Bank's trade-related initiatives have had a moderate impact on corruption up to this point, with any substantial impact in the future depending on the success of its tariff and export initiatives.

\section{Model to Explain the Relationship between Corruption and Trade Liberalization}

In this section, a model is presented to explain the factors that contribute to the level of corruption in an economy. The specific focus is to analyze the effects of trade openness on the level of corruption. But any analysis of corruption must contain a simple model that attempts to discern which particular country-specific factors determine the level of corruption. Thus it would be useful to introduce the simplified model and the relevance of the variables included:

Corruption $=\mathrm{f}$ (Trade Liberalization, Level of Growth, Level of Education, Size and Quality of Bureaucracy, Quality of Judiciary)

\section{Trade Liberalization}

The arguments for how trade liberalization affects corruption have been discussed in length in the previous sections. This analysis follows Ades and di Tella (1997) and an internal Bank research study, which found that elements of trade liberalization had significant effects on the level of corruption.

\section{The Level of Growth}

An analysis of the effects of the level of growth (as measured by the difference in logged GDP) on corruption provides an opportunity to test two interesting hypotheses. One strand of thought would imply that corruption would be more prevalent in an economy that is characterized by high growth (thus more opportunities for corruption) and limited checks (legal, political, etc) on corruption. Thus the possibility exists that in a sample of developing countries, corruption may actually be higher for countries with higher levels of growth. The second point of view would state that corruption is a symptom of a strong economy and that economies that are growing faster are indicating that they have greater 
institutional strengths, which in turn should be reflected by lower levels of corruption. Though the analysis that follows will not perfectly distinguish between both ideas, it will provide an opportunity for an interesting discussion.

\section{The Level of Education}

The mechanism through which the level of education affects corruption is quite intuitive. As Ades and di Tella (1997) and an internal Bank research study briefly discuss, a better-educated population would have a tendency to reduce corruption. This could work in two ways: First, a better educated population will have less tolerance for observing and participating in corruption and will take actions to reduce it. Second, a more highly educated workforce will lead to a more competitive economic environment, which will force illegal rents down. In both cases, more education should lead to less corruption.

\section{Size and Quality of the Bureaucracy}

The size and quality of the bureaucracy (both of which may be inversely related) should be an important factor affecting the level of corruption in an economy. An interesting analysis of the effect of the size of the government on corruption is presented by Goel and Nelson (1998) in which they propose that, "It is, of course, reasonable to expect more political knavery with larger governments. A larger government might also imply greater bureaucratic delay inducing rent-seekers to offer bigger bribes," (page 111). They find that the size of the government, in particular spending by state governments, does have a strong positive influence on corruption. And not only is the size of the bureaucracy important, but as Tanzi (1998) points out, the quality is an important factor that affects corruption indirectly. As Rauch and Evans (1997) found out, the lower is the quality of the bureaucracy (as measured by the number of recruitments and promotions based on merit) the higher is the extent of corruption.

\section{The Quality of the Judiciary}

The quality of the judiciary is a fundamental determinant in the level of corruption in an economy. This is because a corrupt judiciary can be influenced through illegal means (such as bribery), while a weak judiciary is unable to prosecute instances of corruption in civil society. Both of these situations force the economic agents in society to resort to illegal means to get any work done, which can become an accepted norm. As Tanzi (1998) 
points out, "The lack of transparency in rules, laws, and processes creates a fertile ground for corruption," (page 575). Friedman, Johnson, Kaufmann and Zoido-Lobaton (1999) find that, "The relationship between the share of the unofficial economy and the rule of law is strong and consistent," (page 27), which implies that stronger institutions combating corruption lead to smaller unofficial economies.

\section{EMPIRICAL ANALYSIS}

\section{a) Data}

The data used to find the relationship between trade liberalization and corruption will come from various sources. First, the data on World Bank projects related to trade liberalization will come from the World Bank's Adjustment Lending Conditionality and Implementation Database (ALCID). This database conditions all World Bank projects between 1980 and 1997 (categorized by project objectives), with the economic conditionalities (categorized by sector) attached with each loan. For the projects between 1980 and 1990, the ALCID database also contains implementation ratings for the economic conditionalities associated with each project.

Second, for the cross-country indicators, ratings taken from the International Country Risk Guide (ICRG) will be used. This database contains ratings for (a) corruption (ICRGF), (b) bureaucratic quality (ICRGL) and (c) law and order (ICRGI) on a scale from 0 (most corrupt) to 6 (least corrupt) for a sample of 65 countries, for the years 1983-1998. It is useful to note that the indicators are such that as they increase, the variable under consideration increases. Thus as the ICRGF index increases, corruption decreases. Similarly as the IGRGL and ICRGI indicators increase, the qualities of the bureaucracy and judiciary (respectively) increase. Alternately, cross-country indicators are also taken from the Fraser Institute, which contains indices measuring the (a) size of the government (FRAS-I), (b) the monetary policy of the government (FRASIII), (c) the legal structure and level of property rights (FRAS-V) and (d) the freedom to trade with foreigners (FRAS-VI) for the years 1990 and 1997. A third source of cross-country corruption ratings is the Transparency International Rating, though they are only available for the years 1996, 1997 and 1998 (TI96, TI97, TI98).

Finally, other macroeconomic data were incorporated into the analysis. This data consisted of the Real Gross Domestic Product per capita (GDP), the revenues from export duties as a percentage of the total exports 
(EXPDUT), the revenues from import duties as a percentage of total imports (IMPDUT), the level of current government expenditure as a percentage of GDP (GOVCON), the total revenues from taxes on trade as a percentage of GDP (TAXINT), the value of international trade as a percentage of GDP (TRADE) and the level of primary education enrollment (ENRPRM) and higher education enrollment (ENRHIGH). This data is taken from the IMF Government Financial Statistics, IMF Financial Statistics and the World Bank's World Development Indictors (WDI).

\section{b) Statistical Analysis and Results}

The purpose of the statistical analysis is to find the nature and strength of the relationship between the trade liberalization policies and the levels of corruption in countries. The statistical analysis has been performed in two parts. The first section uses a panel of 35 developing and developed countries over the sixteen-year period, 1982-1997, to determine which factors influence the level of corruption. The second section uses a crosssection of 84 countries, for the year 1997, to determine the causes of corruption.

\section{Panel Analysis of the Factors affecting the Level of Corruption}

In this section, it is hypothesized that corruption is dependent on the level of growth in the country, the size of the bureaucracy, the quality of the bureaucracy, the quality of the judiciary, the levels of import and export restrictions (as measured by the revenues from import and export taxes), the international competitiveness of the country (as measured by total amount of trade) and the levels of education.

This analysis uses a pooled data set, comprising 35 countries over the ten-year span from 1982-1997. The variables under analysis are: the level of corruption (represented by ICRGF), the change in the level of development of the country (represented by DLGDP), the change in the quality of the bureaucracy (represented by DICRGL), the change in the quality of the judiciary (represented by DICRGI), the change in the size of the bureaucracy (represented by the proxy variable DGOVCON, measuring current government expenditure), the change in the level of export duties (represented by DEXPDUT), the level of imports (represented by DIMPDUT), the change in the level of trade (represented by DTRADE) and the changes in the levels of primary and higher education enrollment (DENRPRM and DENRHIGH, respectively). 
In the first stage of the analysis, a correlation matrix was calculated for the aforementioned variables, which is included in the Appendix (TableA1). In the second stage of the analysis, a series of regressions were performed to determine the factors influencing the level of corruption and to see if trade expansion and trade liberalization lead to significant differences in the level of corruption. The regressions are conducted on the first differences of the variables mentioned above ${ }^{5}$ and are divided into two sets of regressions, the first including the variable measuring enrollment in higher education and the second excluding that variable. The reason for this division is that the data for enrollment in higher education is sparse and severely curtails the size of the sample used in the analysis. The results are summarized in Tables 1 and 2 below, and it may be worth discussing some of the results in greater detail.

\section{Effects of Trade Liberalization on Corruption}

In the first set of regressions (excluding the higher education variable), the change in the amount of international trade has a small negative effect on the corruption variable (in other words, slightly increased the level of corruption). ${ }^{6}$ It can be hypothesized that increases in the level of international trade, increases both the opportunities for corruption (at the import tax collection and assessment levels) and the level of corruption (i.e. larger bribes may be required for customs officials, etc. since the quantity of tradeables has increased). It should be noted that this effect is very small (and is insignificant in the second set of regressions) and cannot be used as conclusive evidence about the effect of international trade on corruption.

In both sets of regressions, higher levels of import duties lead to higher levels of corruption, though this effect is small. With this result, one can confidently claim that higher import taxes leads to greater opportunities for officials (both in the customs department and in other spheres of government) to collect rents from individuals seeking to either avoid paying duties completely or having the levels of taxes due to be underassessed. It is interesting to note that the results for the effects on corruption of export taxes is not significant. Here one can hypothesize

\footnotetext{
${ }^{5}$ First differences were taken because serial correlation was detected in many of the variables and the null hypothesis of a unit root could not be rejected in the case of ICRGF.

${ }^{6}$ Recall that the corruption variable takes a value of 0 for countries with the highest level of corruption, and a value of 6 for countries with the least corruption, so that an increase in the corruption variable signifies a decrease in the level of corruption in the country.
} 
that though higher export taxes do increase the opportunities for corruption (in the same way that import taxes work), the revenues from export taxes are so much smaller than those for import taxes that taxes on exports will have a negligible effect on the level of corruption. Thus the evidence does point towards the fact that trade liberalizing policies that reduce the levels of trade related taxes do have significant effects on the level of corruption.

\section{Effects of Other Variables on Corruption}

At this stage it would be interesting to see the effect of the other variables on the level of corruption.

It was found that improvements in the rule of law (which includes the strength and impartiality of the legal system and the popular observance of the existing laws) lead to decreases in the level of corruption. This is an intuitively appealing result since it says that a stronger legal system will not only be a staunch prosecutor of officials engaging in corruption, it will also empower the public to take a greater interest (in terms of media attention and direct actions in the court system) in the level of systemic corruption in the economy. This is turn increases the risk and has a tendency to dissuade officials from rent-seeking.

The analysis implies that improvements in the quality of the bureaucracy lead to higher levels of corruption. At first glance this may seem counterintuitive. But, it should be kept in mind that the index of bureaucracy measures the stability of the bureaucracy and its ability to resist political pressure. The possibility exists that a more autonomous bureaucracy may actually give the officials the ability to extract greater rents. This may be the case in a bureaucratic system that was established in the past and is resistant to political and economic change, and thus may not be answerable to both the politicians and the public. But this result should be severely qualified.

Finally, changes in the primary school enrollment rates have no significant effects on corruption. Similarly, changes in the enrollment rates in higher education are also not found to significantly affect the level of corruption. Though this may seem puzzling at first, it could be hypothesized that there exists some threshold level of education that affects corruption. Thus for education to affect corruption, the country has to have a certain minimum level of literacy, after which civil society would take a more active and effective interest in the level of corruption in an economy. 
Table-1: Regression Results for Panel Data without Higher Education Variable: (Tstatistics are in brackets)

\begin{tabular}{|c|c|c|c|c|c|c|c|c|c|c|}
\hline $\begin{array}{c}\text { Dependent } \\
\text { Variable }\end{array}$ & DGDP & DTRADE & DIMPDUT & DEXPDUT & DICRGI & DICRGL & DENRPRM & DGOVCON & $\begin{array}{c}\text { Adjusted } \\
\text { R-squared }\end{array}$ & $\begin{array}{l}\text { \# of } \\
\text { Obs. }\end{array}$ \\
\hline ICRGF & $\begin{array}{l}9.5 \mathrm{E}-17 \\
(0.342)\end{array}$ & $\begin{array}{l}-0.0081 \\
(-1.338)\end{array}$ & $\begin{array}{l}-0.011 \\
(-1.35)\end{array}$ & $\begin{array}{l}-0.00084 \\
(-0.1577)\end{array}$ & $\begin{array}{l}0.325 \\
(4.67)\end{array}$ & $\begin{array}{l}-0.203 \\
(-2.36)\end{array}$ & $\begin{array}{l}0.0031 \\
(0.236)\end{array}$ & $\begin{array}{c}0.0065 \\
(0.3308)\end{array}$ & 0.319 & 254 \\
\hline ICRGF & $\begin{array}{c}-2.7 \mathrm{E}-16 \\
(-3.72)\end{array}$ & $\begin{array}{c}-0.008 \\
(-1.479)\end{array}$ & $\begin{array}{c}-0.010 \\
(-1.387)\end{array}$ & $\begin{array}{l}-0.00071 \\
(-0.1366)\end{array}$ & $\begin{array}{l}0.3097 \\
(4.74)\end{array}$ & $\begin{array}{c}-0.200 \\
(-2.589)\end{array}$ & NA & NA & 0.3229 & 293 \\
\hline ICRGF & $\begin{array}{c}-2.7 \mathrm{E}-16 \\
(-3.77)\end{array}$ & $\begin{array}{l}-0.0083 \\
(-1.502)\end{array}$ & $\begin{array}{l}-0.0092 \\
(-1.229)\end{array}$ & $\begin{array}{l}-0.00099 \\
(-0.1907)\end{array}$ & $\begin{array}{c}0.3504 \\
(5.46)\end{array}$ & NA & NA & NA & 0.3080 & 293 \\
\hline ICRGF & $\begin{array}{c}-2.8 E-16 \\
(-3.808)\end{array}$ & NA & $\begin{array}{l}-0.0077 \\
(-1.065)\end{array}$ & $\begin{array}{c}-0.00148 \\
(-0.288)\end{array}$ & $\begin{array}{l}0.3067 \\
(4.685)\end{array}$ & $\begin{array}{c}-0.2022 \\
(-2.61)\end{array}$ & NA & $\boldsymbol{N A}$ & 0.3241 & 295 \\
\hline
\end{tabular}


Table-2: Regression Results for Panel Data with Higher Education Variable ${ }^{7}$ : (Tstatistics are in brackets)

\begin{tabular}{|c|c|c|c|c|c|c|c|c|c|c|c|}
\hline $\begin{array}{c}\text { Dependent } \\
\text { Variable } \\
\end{array}$ & DGDP & DTRADE & DIMPDUT & DEXPDUT & DICRGI & DICRGL & DENRPRM & $\begin{array}{c}\text { DEN- } \\
\text { RHIGH }\end{array}$ & $\begin{array}{c}\text { DGOV- } \\
\text { CON }\end{array}$ & $\begin{array}{c}\text { Adjusted } \\
\text { R-squared }\end{array}$ & $\begin{array}{l}\text { \# of } \\
\text { Obs. }\end{array}$ \\
\hline ICRGF & $\begin{array}{c}-3.0 \mathrm{E}-16 \\
(1.21)\end{array}$ & $\begin{array}{l}-0.0089 \\
(-1.056)\end{array}$ & $\begin{array}{c}-0.023 \\
(-1.459)\end{array}$ & $\begin{array}{c}0.0019 \\
(0.0049)\end{array}$ & $\begin{array}{l}0.189 \\
(2.49)\end{array}$ & $\begin{array}{l}-0.24 \\
(-2.03)\end{array}$ & $\begin{array}{l}-0.0161 \\
(-0.732)\end{array}$ & $\begin{array}{c}-0.775 \\
(-1.071)\end{array}$ & $\begin{array}{c}0.0091 \\
(0.18)\end{array}$ & 0.385 & 85 \\
\hline ICRGF & $\begin{array}{c}4.05 \mathrm{E}-16 \\
(-1.736)\end{array}$ & $\begin{array}{c}-0.0076 \\
(-0.98)\end{array}$ & $\begin{array}{l}-0.023 \\
(-1.52)\end{array}$ & $\begin{array}{c}0.0034 \\
(0.0936)\end{array}$ & $\begin{array}{l}0.1866 \\
(2.57)\end{array}$ & $\begin{array}{c}-0.277 \\
(-2.433)\end{array}$ & $\begin{array}{c}-0.007 \\
(-0.344)\end{array}$ & $\begin{array}{l}-0.44 \\
(-1.41)\end{array}$ & NA & 0.3977 & 88 \\
\hline ICRGF & $\begin{array}{c}-3.9 \mathrm{E}-16 \\
(-6.74)\end{array}$ & $\begin{array}{c}-0.005 \\
(-0.641)\end{array}$ & $\begin{array}{l}-0.0125 \\
(-0.856)\end{array}$ & $\begin{array}{c}0.0052 \\
(0.1634)\end{array}$ & $\begin{array}{l}0.133 \\
(1.79)\end{array}$ & $\begin{array}{l}-0.272 \\
(-2.47)\end{array}$ & NA & $\begin{array}{c}-0.034 \\
(-1.111)\end{array}$ & NA & 0.435 & 109 \\
\hline ICRGF & $\begin{array}{c}-4.0 E-16 \\
(-6.85)\end{array}$ & NA & $\begin{array}{l}-0.0089 \\
(-0.665)\end{array}$ & $\begin{array}{l}0.0044 \\
(0.137)\end{array}$ & $\begin{array}{l}0.1254 \\
(1.715)\end{array}$ & $\begin{array}{c}-0.279 \\
(-2.55)\end{array}$ & NA & $\begin{array}{l}-0.036 \\
(-1.22)\end{array}$ & NA & 0.439 & 109 \\
\hline
\end{tabular}

\footnotetext{
${ }^{7}$ The regressions have been performed with and without the higher education variable, because of a significant decrease in the number of observations used when the variable is included. The results have to be interpreted with this in mind for the regressions with the higher education variable.
} 


\section{Cross-Sectional Analysis of the Effect of World Bank Initiatives on Corruption}

In this section, three sets of regressions were performed on a sample of 85 countries to see what factors influenced the level of corruption in a particular country and to also evaluate World Bank initiatives in the area of trade policy reforms in terms of their effect on corruption. For all the regressions in this sections, the 1997 Transparency International indicator for (lack of) corruption (TI97) was used to determine the cross-country leve1 of corruption and the Fraser Indices were used to measure the (i) size of the government (FRAS-I-97), (ii) the monetary policy and price stability of the country (FRAS-III-97), and (iii) the legal structure and level of property rights in the country (FRAS-V-97). Similar to the ICRG indicators, it is useful to note that the indicators are such that as they increase, the variable under consideration increases. Thus as the TI97 index increases, corruption decreases. Similarly as the FRAS-V-97 indicator increases, the quality of the judiciary increases. The other variables in the analysis are the quantity of trade as a percentage of GDP (TRADE97), which was used to measure the openness of each economy and the natural $\log$ of the GDP (LGDP-97), which was used to measure the size of the country. The distinguishing feature in each of the regressions was the use of different variables to represent the level of trade openness.

\section{Regressions Using the Fraser Index for Trade Liberalization}

In this set of regressions, the level of trade liberalization in a country is measured by the Fraser index for freedom to trade (FRAS-VI-97). At this point, it would be useful to discuss the nature of the Fraser index on freedom of trade. The index is a weighted average of: (i) revenues from international trade as a percentage of exports and imports $(0.214)$, (ii) the mean tariff rate $(0.227)$, (iii) the standard deviation of tariff rates $(0.117)$, (iv) the percent of international trade covered by non-tariff restraints $(0.198)$, (v) the actual size of the trade sector compared to the expected size $(0.105)$, and (vi) the difference between the official and black market exchange rate $(0.139)^{8}$. The results of the regressions are presented in Table 3 . The Appendix contains a correlation matrix for the variables used in the regression analysis (Table A2).

8 Principal component analysis was used to determine the weight given to each component in the construction of the area index. This procedure partitions the variance of a set of variables and uses it to determine the linear combination--the weights--of these variables that maximizes the variation of the newly constructed principal component. In effect, the newly constructed principal component--an area rating, for example--is the variable that most fully captures the variation of the underlying components. 
The regressions using the Fraser index show that trade openness has a significantly large effect on corruption, or that the more liberal the trade regime of a country, the lower is the level of corruption. Since the Fraser index takes into account tariff and non-tariff barriers, it can be reasonably hypothesized that lower tariff and non-tariff barriers lead to fewer opportunities for rent-seeking (in terms of taking bribes for lower tax payments or exemptions). Not only do the opportunities for rent-seeking decrease, but the increased competitiveness of the economy that results from trade liberalization leads to lower available rents.

\section{Regressions Using Project Implementation Ratings for Trade Liberalization}

For this section, 114 trade-related projects, implemented between the years of 1980 and 1990, were chosen from the World Bank's Adjustment Lending Conditionality and Implementation Database (ALCID). Projects were chosen based on the fact that corruption indicators were available for the country and that the projects had implementation ratings. The trade related conditionalities in each project were first divided into three categories: (i) the reduction (and total elimination) of tariffs, (ii) export related initiatives (which were defined as policies that were related directly to export promotion and those that were related to reductions in export taxes) and (iii) the reduction (and total elimination) of quotas. The second step was to determine the average implementation ratings for the conditionalities in each of the areas mentioned above; thus each project had an average rating for quota reducing initiatives, tariff reducing initiatives and export related initiatives. Again it is useful to note that the higher is average implementation rating the more successful the project. Finally, each country (of the total 85 countries) was given a rating in the area of tariff reduction (ITTR), export related initiatives (ITEX) and quota reduction (ITQR), based on the averages calculated above. The purpose of these variables was to test if successful implementation of the Bank's trade related initiatives had a significant effect on corruption.

The regressions using the World Bank's implementation ratings for trade related projects yielded interesting results, and are shown in Table 4. As the implementation ratings for tariff reduction policies and export related initiatives increase (i.e. the policies are implemented successfully by the country), the level of corruption decreases. Thus countries that successfully implement the Bank's tariff and export related conditionalities have a tendency to have lower levels of corruption. But, increases in the implementation ratings for conditionalities dealing with quota reductions had no impact on the level of corruption. This is perhaps due to the fact 
that most quotas are replaced with a system of tariffs, so there is no significant decrease in corruption. Also (as in the last section), the tariff related initiatives have a greater effect on the level of corruption than the export related initiatives. This can be attributed to two factors. First, tariff revenues are much larger than export tax revenues, and thus changes in tariff policy have a greater effect on reducing the opportunities for rentseeking. Second, in practice, import tariffs have a larger effect on the international competitiveness of an economy than more limited export taxes. Thus as import tariffs are reduced, competitiveness increases and the level of illegal rents (and the level of corruption) are driven down.

\section{Regressions Using OED Outcome Ratings}

The third part of this analysis replaces the implementation ratings used above with average OED outcome ratings for trade-related projects in the 85 countries under analysis ${ }^{9}$. The purpose of this is to see if countries with 'successful' (as evaluated by the OED) trade-related projects had lower levels of corruption. To obtain an average trade-related outcome rating (OEDOUT) for each country, all the trade related projects from that country were taken, and the outcome ratings (which are either Satisfactory (1) or Unsatisfactory (0)) were averaged over the projects. The results are summarized in Table-5 (with the correlation matrix in the Appendix, Table A2) and yield some interesting conclusions.

It was found that countries whose trade related projects have been given a satisfactory OED outcome rating have significantly lower levels of corruption than countries with projects that have been found to be unsatisfactory. Though there has been no distinction made between what different types of projects (e.g. projects that deal with quota reduction or tariff reduction), the conclusion can be drawn that World Bank initiatives in the area of trade reform have had significant effects on levels of corruption, over the period 1980-1997.

At this point, it is interesting to note that the level of trade in an economy is not a significant determinant of the level of corruption, in any of the three sets of regressions. Since the analysis is a cross-country analysis, one can hypothesize that even though changes in the level of trade (as was measured in the regressions of the previous section) may affect the level of corruption (because greater trade may either increase opportunities for corruption or increase competitiveness and decrease

\footnotetext{
${ }^{9}$ Note that OED outcome ratings are for projects implemented between the years 19801997.
} 
corruption), the actual level of trade may not affect corruption. In other words, just because one country trades more than another country, this does not mean that it is more susceptible to corruption. Rather, if there are significant changes in the level of trade within a country, the level of corruption is affected.

\section{The Effect of other Variables on Corruption}

It is also illustrative to analyze the effects of the other included variables on the level of corruption. First, it was seen that corruption is significantly affected by the size of the government. The results imply (as were previously found) that countries with larger governments have a tendency to be more susceptible to corruption. This is because a larger government implies an increased number of rules and regulations, including licenses, permits and authorizations of various types. The resulting monopoly power of the state enables it to extract illegal rents or engage in other acts of corruption.

Secondly, it was found that corruption is significantly affected by the legal structure and quality of property rights in a country. Thus a country with greater security of property rights and viability of contracts tends to have less corruption than countries that do not benefit from these characteristics. This is because people will take more actions to catch perpetrators of corruption if they think that the judicial system is willing to punish acts of corruption. Also, countries with strong judicial systems have a tendency to take direct actions against corruption, such as setting up anticorruption commissions or ethics offices. However, it should be noted that the existence of such commissions does not guarantee lower levels of corruption.

Table-3: Regression Results for Cross-country Analysis, Using Fraser Index of Trade Openness: (T-statistics are in brackets)

\begin{tabular}{ccccccccc}
\hline $\begin{array}{c}\text { Dependent } \\
\text { Variable }\end{array}$ & $\begin{array}{c}\text { FRAS- } \\
\text { I-97 }\end{array}$ & $\begin{array}{c}\text { FRAS- } \\
\text { III-97 }\end{array}$ & $\begin{array}{c}\text { FRAS- } \\
\text { V-97 }\end{array}$ & $\begin{array}{c}\text { FRAS- } \\
\text { VI-97 }\end{array}$ & $\begin{array}{c}\text { TRADE } \\
\mathbf{- 9 7}\end{array}$ & $\begin{array}{c}\text { LGDP- } \\
\text { 97 }\end{array}$ & $\begin{array}{c}\text { Adjusted } \\
\text { R-squared }\end{array}$ & $\begin{array}{c}\text { \# of } \\
\text { Obs. }\end{array}$ \\
\hline TI97 & -0.478 & 0.0932 & 0.339 & 0.268 & 0.009 & -0.0737 & & \\
& $(-2.61)$ & $(1.29)$ & $(1.412)$ & $(1.85)$ & $(0.74)$ & $(-0.566)$ & 0.35 & 41 \\
T197 & -0.529 & 0.107 & -0.285 & 0.328 & NA & NA & 0.42 & 43 \\
& $(-3.56)$ & $(-1.65)$ & $(-1.413)$ & $(2.66)$ & & & & \\
T197 & -0.449 & NA & 0.482 & 0.309 & NA & NA & 0.387 & 43 \\
& $(-3.096)$ & & $(2.159)$ & $(2.443)$ & & & & \\
\hline
\end{tabular}


Table- 4: Regression Results for Cross-country Analysis, Regressions Using Project Implementation Ratings for Trade Liberalization: (T-statistics are in brackets)

\begin{tabular}{cccccccccccc}
\hline $\begin{array}{c}\text { Dependen } \\
\text { t } \\
\text { Variable }\end{array}$ & $\begin{array}{c}\text { FRAS- } \\
\text { I-97 }\end{array}$ & $\begin{array}{c}\text { FRAS- } \\
\text { III-97 }\end{array}$ & V-97 & $-\mathbf{- 9 7}$ & $\mathbf{9 7}$ & & & & \multicolumn{3}{c}{$\begin{array}{c}\text { Adjusted } \\
\text { R-squared Obs. }\end{array}$} \\
\hline TI97 & -0.184 & 0.016 & 0.465 & 0.019 & -0.179 & 0.017 & 0.018 & 0.012 & 0.219 & 23 \\
& $(-0.859)$ & $(0.175)$ & $(1.80)$ & $(1.13)$ & $(-1.36)$ & $(0.966)$ & $(1.33)$ & $(0.632)$ & & \\
TI97 & -0.24 & 0.011 & 0.621 & NA & -0.22 & 0.019 & 0.033 & 0.009 & 0.202 & 23 \\
& $(-1.14)$ & $(0.127)$ & $(2.83)$ & & $(-1.75)$ & $(1.05)$ & $(1.37)$ & $(0.481)$ & & \\
TI97 & -0.23 & NA & 0.62 & NA & -0.21 & 0.018 & 0.032 & 0.008 & 0.262 & 23 \\
& $(-1.29)$ & & $(2.95)$ & & $(-2.02)$ & $(1.13)$ & $(1.55)$ & $(0.48)$ & & \\
TI97 & -0.391 & 0.114 & 0.515 & 0.024 & -0.24 & NA & 0.066 & 0.029 & 0.466 & 24 \\
& $(-1.622)$ & $(1.36)$ & $(1.96)$ & $(1.41)$ & $(-1.799)$ & & $(3.09)$ & $(1.51)$ & & \\
TI97 & -0.258 & NA & 0.572 & 0.024 & -0.17 & NA & 0.06 & 0.033 & 0.439 & 24 \\
& $(-1.14)$ & & $(2.15)$ & $(1.37)$ & $(-1.37)$ & & $(2.8)$ & $(1.66)$ & & \\
TI97 & -0.335 & NA & 0.745 & NA & -0.209 & NA & 0.061 & 0.029 & 0.412 & 24 \\
& $(-1.49)$ & & $(3.11)$ & & $(-1.635)$ & & $(2.76)$ & $(1.44)$ & & \\
\hline
\end{tabular}

Table -5: Regression Results for Cross-country Analysis, Using OED Outcome Ratings:

(T-statistics are in brackets)

\begin{tabular}{|c|c|c|c|c|c|c|c|c|}
\hline $\begin{array}{c}\text { Dependent } \\
\text { Variable }\end{array}$ & $\begin{array}{c}\text { FRAS-I- } \\
97\end{array}$ & $\begin{array}{l}\text { FRAS- } \\
\text { III-97 }\end{array}$ & $\begin{array}{l}\text { FRAS- } \\
\text { V-97 }\end{array}$ & $\begin{array}{c}\text { TRADE } \\
-97\end{array}$ & $\begin{array}{c}\text { LGDP- } \\
97\end{array}$ & SEDOUT & $\begin{array}{l}\text { Adjusted } \\
\text { R-squared }\end{array}$ & $\begin{array}{l}\text { \# of } \\
\text { Obs. }\end{array}$ \\
\hline TI97 & $\begin{array}{l}-0.324 \\
(-2.01)\end{array}$ & $\begin{array}{c}0.031 \\
(-0.46)\end{array}$ & $\begin{array}{c}0.47 \\
(2.05)\end{array}$ & $\begin{array}{l}0.006 \\
(0.45)\end{array}$ & $\begin{array}{l}-0.099 \\
(-0.86)\end{array}$ & $\begin{array}{c}1.64 \\
(2.57)\end{array}$ & 0.327 & 39 \\
\hline T197 & $\begin{array}{l}-0.304 \\
(-1.91)\end{array}$ & $\begin{array}{l}-0.037 \\
(-0.56)\end{array}$ & $\begin{array}{c}0.377 \\
(1.873)\end{array}$ & $\begin{array}{c}0.01 \\
(0.793)\end{array}$ & NA & $\begin{array}{c}1.684 \\
(2.332)\end{array}$ & 0.387 & 39 \\
\hline TI97 & $\begin{array}{c}-0.334 \\
(-2.107)\end{array}$ & $\begin{array}{l}-0.032 \\
(-0.48)\end{array}$ & $\begin{array}{l}0.510 \\
(2.43)\end{array}$ & NA & $\begin{array}{c}-0.117 \\
(-1.091)\end{array}$ & $\begin{array}{c}1.68 \\
(2.69)\end{array}$ & 0.343 & 39 \\
\hline T197 & $\begin{array}{l}-0.317 \\
(-2.03)\end{array}$ & $\begin{array}{c}-0.0362 \\
(-0.56)\end{array}$ & $\begin{array}{l}0.407 \\
(2.15)\end{array}$ & NA & NA & $\begin{array}{l}1.710 \\
(2.86)\end{array}$ & 0.339 & 40 \\
\hline
\end{tabular}

\section{Part-VI: Conclusions}

This paper attempted to define the relationship between corruption and trade liberalization. The reason for this was to: (1) determine which elements of a trade liberalization policy will significantly affect corruption, 
(2) determine the effects of the World Bank's trade liberalization policies on the level of corruption and (3) empirically determine the effect that trade liberalization has on corruption.

The World Bank's trade liberalization policy focuses on four major initiatives, each of which has a different effect on the level of corruption in an economy. The following results were found:

(i) The removal of non-tariff barriers has been implemented with substantial success by the World Bank. Though this implies a decrease in corruption because of the reduction in the incentives to circumvent these barriers, experience has shown that these barriers are usually replaced with tariffs, which increase the level of corruption. Thus, the impact of this policy on corruption is modest and the overall impact of the Bank's policies in this area is modest.

(ii) The reduction (and abolition) of tariffs can lead to a substantial decline in corruption at both the tax collection level and at the importer level. Lower tariffs mean less corruption when government officials assess and collect taxes. Similarly, lower tariffs mean fewer bribes to officials from business people trying to protect their industries (with the imposition of tariffs) or importers trying to liberalize their sector (with the removal of tariffs). Finally lower tariffs mean more trade, which increases the competitiveness of the economy, which in turn reduces the opportunities for rent-seeking. But World Bank initiatives in this area have had modest success, and thus the overall impact of Bank initiatives in this area is modest.

(iii) Though initiatives to promote exports and remove export taxes should lead to substantial declines in the level of corruption, the impact of the World Bank's initiatives in this area have been modest. Taxes on exports are susceptible to corruption at the assessment and collection stages, and reductions in these taxes should reduce the illegal rents available to corrupt officials. Export promotion schemes should lead to higher volumes of trade, making the economic environment more competitive. This in turn should drive down the levels of the illegal rents. But empirical evidence shows that the effect of export taxes on corruption is far lower than that of import taxes (which reduces the role of export taxes in fighting corruption), and that export promotion schemes have had little impact on the level of trade. This implies that the export related initiatives have had only modest effects on corruption. Since the Bank's policies in the area of export promotion 
have also had modest success, the overall impact of the Bank's export promotion policies has been modest.

(iv) Exchange rate policies have a substantial effect on corruption because they usually reduce the black market premium, which should reduce corruption in the foreign exchange market. These policies also promote trade, which in turn makes the economy more competitive and reduces the level of illegal rents available. Finally, successful exchange rate policies tend to complement other policies of trade liberalization (such as tariff reform and export promotion), which in turn lead to further reductions in corruption. The World Bank has made substantial progress in the area of exchange rate reform, which in turn implies that these initiatives have had a substantial overall impact on the level of corruption.

A statistical analysis also sheds light upon the relationship between corruption and trade liberalization. Using different measurements of corruption, it was found that:

(1) Higher import duties led to higher corruption, which implies that successful policies aimed at tariff reform should reduce the level of corruption in an economy.

(2) Higher export taxes had a negligible effect on the level of corruption, which in turn implies that successful policies aimed at export promotion have little impact on the level of corruption.

(3) Absolute levels of the quantity of trade of a country have little impact on the level of corruption, but changes have a small impact. This means that a country that trades more does not necessarily have a higher level of corruption. Rather, a country that experiences a large increase in their quantity of trade will possibly also experience a slight increase in their level of corruption.

(4) The greater the success with which World Bank policies on tariff reduction have been implemented in a particular country, the lower is the level of corruption in that country. Thus World Bank initiatives in the area of tariff reform have been successful in reducing the level of corruption.

(5) The success of World Bank initiatives in the sphere of export promotion has had little effect on the level of corruption. This is mainly because successful export promotion has focused on the 
reduction in export taxes (that are significantly smaller than import tariffs), while expansion in the level of exports has been less of a focus and less successfu1.

(6) The openness of the economy (in terms of the level of trade and the level of tariff and non-tariff barriers) has had a significant effect on the level of corruption. Thus in general, when the economy becomes more open, the level of corruption has a tendency to decrease.

(7) It was found that countries whose trade related projects have been given a satisfactory OED outcome rating have significantly lower levels of corruption than countries with projects that have been found to be unsatisfactory. Thus, 'successful' (as found by the OED) World Bank initiatives in the area of trade reform have had significant effects on levels of corruption, over the period 19801997.

Thus it was found that trade liberalization has a significant impact on the level of corruption. It was also determined that one of the most potent tools of trade liberalization in combating corruption is the reduction in import tariffs. But the sequencing of trade policy reforms is such that before one can reduce import duties and successfully expand the level of exports (both of which reduce the level of corruption), one has to go through exchange rate rationalization and the removal of non-tariff barriers.

The World Bank's trade liberalization policy has succeeded in getting through the first two steps of the sequence, i.e. exchange rate rationalization and the removal of non-tariff barriers. It is steadily making progress in the aim to reduce and eventually abolish import tariffs, and it is this initiative that has lead to the most significant decreases in the level of corruption. But for corruption to continue to decrease, further progress must be made in the sphere of tariff reduction and export promotion. 


\section{APPENDIX}

\begin{tabular}{|c|c|c|c|c|c|c|c|c|c|c|}
\hline & ICRGF & ICRGI & ICRGL & GDP & TRADE & IMPDUT & EXPDUT & GOVCON & ENRPRM & $\begin{array}{c}\text { ENRHIG } \\
\mathbf{H}\end{array}$ \\
\hline ICRGF & 1.0000 & & & & & & & & & \\
\hline ICRGI & 0.3152 & 1.0000 & & & & & & & & \\
\hline ICRGL & 0.1484 & 0.4695 & 1.0000 & & & & & & & \\
\hline GDP & -0.0284 & 0.0974 & 0.0611 & 1.0000 & & & & & & \\
\hline TRADE & 0.0206 & 0.0911 & 0.0746 & -0.0248 & 1.0000 & & & & & \\
\hline IMPDUT & -0.0456 & -0.2506 & -0.0416 & -0.1594 & 0.0779 & 1.0000 & & & & \\
\hline EXPDUT & -0.0984 & -0.1895 & -0.2095 & -0.0455 & -0.2369 & 0.1641 & 1.0000 & & & \\
\hline GOVCON & -0.0487 & -0.0916 & -0.0245 & -0.0359 & 0.3696 & 0.2851 & -0.1021 & 1.0000 & & \\
\hline ENRPRM & 0.0732 & 0.1452 & -0.0298 & 0.0599 & 0.1311 & -0.4583 & -0.2617 & -0.0780 & 1.0000 & \\
\hline ENRHIGH & 0.0106 & 0.3667 & 0.1434 & 0.1367 & 0.1588 & -0.1891 & -0.3361 & -0.0780 & 0.0245 & 1.0000 \\
\hline
\end{tabular}

Table-A1: Correlation Between Corruption Indicator and Other Variables

Table-A2: Correlation Between Corruption and Other Variables:

\begin{tabular}{|c|c|c|c|c|c|c|c|c|c|c|}
\hline & TI97 & FRAS-I-97 & FRAS-III-97 & FRAS-V-97 & FRAS-VI-97 & LGDP-97 & ITQR & ITTR & ITEX & OEDOUT \\
\hline TI97 & 1.000 & & & & & & & & & \\
\hline FRAS-I-97 & -0.421 & 1.000 & & & & & & & & \\
\hline
\end{tabular}




\begin{tabular}{|c|c|c|c|c|c|c|c|c|c|c|}
\hline FRAS-III-97 & 0.191 & 0.169 & 1.000 & & & & & & & \\
\hline FRAS-V-97 & 0.470 & -0.114 & 0.430 & 1.000 & & & & & & \\
\hline FRAS-VI-97 & 0.347 & -0.190 & 0.064 & 0.249 & 1.000 & & & & & \\
\hline LGDP-97 & 0.065 & -0.013 & 0.201 & 0.621 & 0.163 & 1.000 & & & & \\
\hline ITQR & 1.000 & -0.421 & 0.191 & 0.470 & 0.347 & 0.065 & 1.000 & & & \\
\hline ITTR & 0.201 & 0.255 & -0.166 & -0.259 & 0.082 & -0.019 & 0.201 & 1.000 & & \\
\hline ITEX & 0.391 & -0.343 & 0.040 & 0.100 & 0.003 & -0.040 & 0.391 & -0.130 & 1.000 & \\
\hline OEDOUT & 0.332 & 0.206 & 0.253 & 0.342 & 0.234 & 0.128 & 0.332 & -0.014 & -0.035 & 1.000 \\
\hline
\end{tabular}




\section{References}

Ades, Alberto and Rafael di Tella, 1995, "Competition and Corruption," Applied Economics Discussion Paper Series No. 169, Oxford: Oxford University.

Ades, Alberto and Rafael di Tella, 1996, "The Causes and Consequences of Corruption: A Review of Recent Empirical Contributions," IDS Bulletin, April, Volume 29, No. 2, pp. 6-11.

Ades, Alberto and Rafael di Tella, 1997, "National Champions and Corruption: Some Unpleasant Interventionist Arithmetic", The Economic Journal, July, No 107, pp. 1023-1042.

Anderson, J., and Douglas Marcouiller, 1999, "Trade, Insecurity and Home Bias: An Empirical Investigation," National Bureau of Economic Research, Working Paper Number 7000, Cambridge, Massachusetts.

Dean, J., S. Desai, and J. Riede1, 1994, Trade Policy Reform in Developing Countries since 1985. A Review of the Evidence, Washington D.C., World Bank Discussion Paper No. 267.

Edwards, Sebastian, 1997, "Trade Liberalization Reforms and the World Bank," AEA Papers and Proceedings, May, Volume 87, No.2, pp. 43-48.

Friedman, Eric, Simon Johnson, Daniel Kaufmann, an Pablo Zoido-Lobaton, 1999, "Dodging the Grabbing Hand: The Determinants of Unofficial Activity in 69 Countries," Washington D.C., The World Bank.

Goe1, Rajiv and Michael Nelson, 1998, "Corruption and government size: A disaggregated analysis,” Public Choice, N. 97, pp. 107-120.

Kaufmann, Danie1, Aart Kraay and Pablo Zoido-Lobaton, 1999, "Governance Matters,” World Bank Policy Research Working Paper No. 2196, Washington D.C., The World Bank.

Lambsdorff, Johann, 1998, “An Empirical Investigation of Bribery in International Trade," European Journal of Development Research, June, Volume 10, No. 1, pp. 40-59.

Nash, John and Wendy Takacs (eds), 1998, Trade Policy Reform. Lessons and Implications, Washington D.C., The World Bank Regional and Sectoral Studies. 
Papageorgiou, D., M. Michaely and A Choksi, 1990, Liberalizing Foreign Trade in Developing Countries: Lessons of Experience Vol. 1. Washington, DC: The World Bank.

Pritchett, Lant and Geeta Sethi, 1994, "Tariff Rates, Tariff Revenue, and Tariff Reform: Some New Facts," The World Bank Economic Review, Vol. 8, No. 1, pp. 1-16.

Rauch, James E., and Peter B. Evans, 1997, "Bureaucratic Structure and Bureaucratic Performance in Less Developed Countries," (unpublished: San Diego, California and Berkeley, California: University of California at San Diego; University of California at Berkeley).

Tanzi, Vito, 1998, "Corruption Around the World. Causes, Consequences, Scope and Cures,"IMF Staff Papers, Vo1. 45, No. 4 (December), pp. 550-594.

Thomas, V., J. Nash and Associates, 1991, Best Practices in Trade Policy Reform, Oxford: Oxford University Press.

World Bank. 1997, Helping Countries Combat Corruption: The Role of the World Bank, Poverty Reduction and Economic Management Network. Washington DC. 